\title{
List of Acronyms
}

\author{
FBT False Belief Task \\ IT Interaction Theory \\ ST Simulation Theory \\ ToM Theory of Mind \\ TT Theory Theory
}


